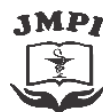

Jurnal Mandala Pharmacon Indonesia, Vol 4.No.1 Juni 2018

Avaiable online at www.jurnal-pharmaconmw.com/jmpi

p-ISSN : 2442-6032

$e$-ISSN : 2598-9979

\title{
Uji Efektivitas Fraksi Daun Salam Terhadap Kadar Kolesterol Total Tikus Putih Jantan Hiperkolesterolemia-Diabetes
}

Wayan wirawan

Akademi Farmasi Medika Nusantara Palu

\begin{abstract}
ABSTRAK
Kolesterol merupakan salah satu bagian dari lemak sebagai salah satu zat gizi yang diperlukan tubuh dan penghasil kalori paling tinggi. Kandungan flavonoid dalam daun salam bersifat sebagai hipolipidemia dan antioksidan yang dapat menghambat stress oksidatif. Penelitian ini bertujuan untuk mengetahui efektivitas daun salam dan untuk mengetahui fraksi yang efektif dalam menurunkan kolesterol total tikus. Ekstrak dibuat secara maserasi dengan etanol 96\% selanjutnya difraksinasi dengan pelarut $n$-heksan dan etil asetat. Hewan hiperkolesterolemia-diabetes dibuat dengan diberi pakan tinggi kolesterol dan diinduksi streptozotocin $30 \mathrm{mg} / \mathrm{kg}$ BB. Hewan uji terbagi 6 kelompok, setiap kelompok terdiri dari 5 ekor. Kelompok I sebagai Kontrol normal yang diberikan pakan standar dan $\mathrm{Na}$ CMC 0,5\%, kelompok II diberikan Na CMC 0,5\% sebagai Kontrol negatif, kelompok III diberikan simvastatin sebagai Kontrol positif, kelompok IV diberikan fraksi n-
\end{abstract}

\section{PENDAHULUAN}

Kehidupan masyarakat modern yang serba instan dengan mengabaikan gaya hidup sehat merupakan penyebab resiko terjadinya penyakit degeneratif. Penyakit degeneratif merupakan suatu penyakit akibat fungsi atau struktur organ tubuh heksan, kelompok $\mathrm{V}$ diberikan fraksi etil asetat dan kelompok VI diberikan fraksi etanol air dosis masingmasing $200 \mathrm{mg} / \mathrm{kg}$ BB. Data yang diperoleh dianalisis menggunakan uji statistic One Way Anova pada taraf kepercayaan 95\%. Hasil analisis menunjukkan bahwa fraksi $n$-heksan, fraksi etil asetat dan fraksi etanol air memiliki efektivitas antikolesterol dan fraksi $n$-heksan dosis $200 \mathrm{mg} / \mathrm{kg}$ BB efektif dalam menurunkan kadar kolesterol total tikus sebanding dengan simvastatin dan dengan Kontrol normal.

Kata kunci :Syzygium polyanthum, HiperkolesterolDiabetes, Streptozotocin, tikus Putih Jantan.

\section{Penulis korespondensi :}

Wayan wirawan

Akademi Farmasi Medika Nusantara Palu

E-mail : wirawanwayan9@gmail.com menurun. Hal ini disebabkan kurangnya melakukan aktivitas dan pola makan yang telah bergeser dari makanan yang berserat dan rendah kalori menuju makanan yang siap saji dan berkalori tinggi. Salah satu penyakit degeneratif yang cenderung 
mengalami peningkatan yaitu penyakit hiperkolesterolemia.

Hiperkolesterolemia adalah peningkatan kadar kolesterol di dalam darah melebihi batas yang diperlukan oleh tubuh. Seseorang dikatakan menderita hiperkolesterolemia bila kadar kolesterol total plasma melebihi keadaan normal, yaitu diatas $200 \mathrm{mg} / \mathrm{dL}$. Kolesterol merupakan salah satu bagian dari lemak sebagai salah satu zat gizi yang diperlukan tubuh dan penghasil kalori paling tinggi. Kolesterol tinggi atau hiperkolesterolemia adalah kondisi dimana tingkat kolesterol dalam darah melampaui kadar normal. Kondisi kolesterol tinggi dapat menimbulkan terjadinya penyakit stroke dan serangan jantung.

Salah satu tanaman tradisional yang digunakan untuk obat kolesterol adalah daun salam (Syzygium polyanthum (Wight) Walp). Penelitian yang telah dilakukan sebelumnya menyatakan bahwa daun salam (Syzygium polyanthum (Wight) Walp) mengandung tanin galat, galokatekin, flavonoid, saponin, dan minyak atsiri (seskuiterpen). Selain itu, daun salam juga mengandung beberapa vitamin, diantaranya vitamin A, vitamin C, Vitamin
E, Thiamin, Riboflavin, Niacin, vitamin B6, vitamin B12 dan folat.

Berdasarkan Penelitian terdahulu menyatakan bahwa penelitian efek infusa daun salam menyatakan bahwa pada konsentrasi 5\%, 10\% dan 20\% menurunkan kadar kolesterol total darah tikus model dislipidemia galur wistar (Prahastuti, 2011). Pada penelitian efek ekstrak etanol daun salam menyatakan bahwa pada dosis 50 $\mathrm{mg} / \mathrm{kgBB}, 100 \mathrm{mg} / \mathrm{kgBB}$, dan 200 mg/kgBB juga mampu menurunkan kadar kolesterol total serum tikus wistar jantan (Ratnawati,2015). Pada penelitian uji aktivitas antidislipidemia in fivo fraksi ekstrak daun salam pada tikus galur wistar yang diinduksi diet tinggi lemak menyatakan bahwa pemberian fraksi etil asetat ekstrak daun salam pada tikus putih galur wistar yang diinduksi diet tinggi lemak dengan dosis 20mg/200gBB setiap hari selama 21 hari dapat menurunkan kadar trigliserida serum tikus secara bermakna dengan $\mathrm{p}=0,033$ danfraksi $\mathrm{n}$ heksan ekstrak daun salam dengan dosis yang sama dapat meningkatkan kadar kolestrol HDL serum tikus secara bermakna dengan $p=0,030$. Sementara tidak terdapat perbedaan bermakna pada kolestrol total 
dan koletrol LDL sebelum dan setelah perlakuan (Irmadoly,2014).

Tujuan penelitian ini adalah untuk mengetahui efek daun salam dan untuk mengetahui fraksi yang efektif untuk kadar kolesterol total tikus putih jantan hiperkolesterolemia-diabetes.

\section{METODE PENELITIAN}

\section{Pembuatan Ekstrak Etanol Daun Salam}

Serbuk simplisia diekstraksi secara maserasi menggunakan pelarut etanol 96\%. Serbuk simplisia ditimbang sebanyak 500 gram lalu dimasukkan ke dalam bejana maserasi dengan menggunakan pelarut etanol sebanyak 2,5 L ditutup, lalu dibiarkan selama 3×24 jam terlindung dari cahaya sambil sesekali diaduk.Ekstrak disaring menggunakan kertas saring lalu diperoleh filtrat, dievaporasi menggunakan Rotavapor pada suhu $60^{\circ} \mathrm{C}$ dan dilanjutkan dengan pengentalan yang dilakukan dengan menggunakan waterbath dengan suhu $60^{\circ} \mathrm{C}$ sampai menjadi ekstrak kental.

\section{Pembuatan Fraksi Daun Salam}

Ekstrak kental etanol 96\% difraksinasi dengan $n$-heksan dan air (1:3) dalam corong pisah dan dikocok secukupnya. Setelah itu dibiarkan sampai terbentuk 2 lapisan yaitu lapisan $n$-heksan dan lapisan air. Perlakuan dilakukan sebanyak 3 kali pengulangan sehingga diperoleh fraksi $n$-heksan. Lapisan air kemudian difraksinasi dengan etil asetat (3:1) sebanyak 3 kali pengulangan seperti perlakuan diatas sehingga diperoleh fraksi air dan fraksi etil asetat. Semua fraksi air, etil asetat dan $n$-heksan diuapkan secara in vacuo.

\section{Analisis data}

Data yang diperoleh berupa kadar kolesterol total yang diukur menggunakan alat ukur cholest test (mission ultra) dan cholest strip (mission ultra) kemudian data yang diperoleh dianalisis menggunakan uji statistik one way ANOVA pada taraf kepercayaan 95\%. Selanjutnya akan dilakukan uji lanjut Post Hoc least significant difference (LSD). Pengolahan data dilakukan menggunakan program Softwarke SPSS 23. (Tandi J. 2017).

\section{Hasil Dan Pembahasan}

Tabel 1. Hasil Uji Fitokimia

\begin{tabular}{|c|c|c|c|c|c|}
\hline No & Kandu & Pereak & \multicolumn{3}{|c|}{ Fraksi Daun Salam } \\
\cline { 4 - 6 } & $\begin{array}{c}\text { ngan } \\
\text { kimia }\end{array}$ & si & $\begin{array}{c}\text { Fraks } \\
\text { i } n- \\
\text { heks } \\
\text { an }\end{array}$ & $\begin{array}{c}\text { Fraks } \\
\text { i Etil } \\
\text { Aseta } \\
\mathrm{t}\end{array}$ & $\begin{array}{c}\text { Fraks } \\
\mathrm{i} \\
\text { Etan } \\
\text { ol air }\end{array}$ \\
\hline 1. & $\begin{array}{c}\text { Alkaloi } \\
\mathrm{d}\end{array}$ & $\begin{array}{c}\text { Dragen } \\
\text { drof }\end{array}$ & + & - & + \\
\hline 2. & $\begin{array}{c}\text { Flavon } \\
\text { oid }\end{array}$ & $\begin{array}{c}\text { HCl } \\
\text { pekat } \\
\text { dan } \\
\text { logam } \\
\text { Hg }\end{array}$ & + & + & + \\
\hline 3. & $\begin{array}{c}\text { Saponi } \\
\mathrm{n}\end{array}$ & $\begin{array}{c}\text { Dikoco } \\
\mathrm{k}+\end{array}$ & + & + & + \\
\hline
\end{tabular}




\begin{tabular}{|c|c|c|c|c|c|}
\hline & & $\begin{array}{c}\mathrm{HCl} 2 \\
\mathrm{~N}\end{array}$ & & & \\
\hline 4. & Tanin & $\mathrm{FeCl}_{3}$ & + & + & + \\
\hline 5. & Fenolik & $\begin{array}{c}\mathrm{FeCl}_{3} \\
5 \%\end{array}$ & + & - & + \\
\hline 6. & $\begin{array}{c}\text { Triterp } \\
\text { enoid }\end{array}$ & $\begin{array}{c}\text { Liberm } \\
\text { en } \\
\text { Buchar } \\
\mathrm{d}\end{array}$ & - & + & - \\
\hline
\end{tabular}

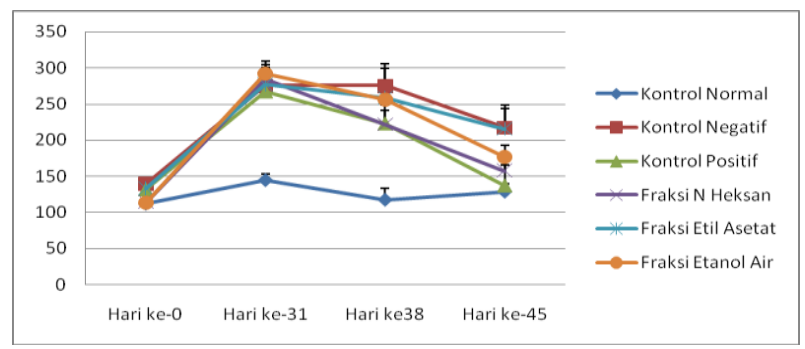

Sumber Data Primer 2017

Gambar1 : Grafik Kadar Kolesterol Total darah

\section{Pembahasan}

Penelitian ini dilakukan untuk mengetahui efek kadar kolesterol total fraksi daun salam (Syzygium polyanthum (Wight) Walp) pada tikus putih jantan hiperkolesterolemia-diabetes. Bahan uji yang digunakan yaitu daun salam (Syzygium polyanthum (Wight) Walp) yang diperoleh disekitaran Kabupaten Parigi Moutong, Provinsi Sulawesi Tengah.

Untuk memastikan jenis daun salam yang digunakan maka dilakukan identifikasi tanaman yang dilaksanakan di UPT. Sumber Daya Hayati Sulawesi Tengah Universitas Tadulako dan hasilnya menunjukan bahwa benar bahan uji yang digunakan adalah daun salam (Syzygium polyanthum (Wight) Walp) dari Suku Myrtaceae.

Metode ekstraksi yang digunakan dalam penelitian yaitu metode maserasi. Maserasi merupakan salah satu teknik penyarian yang dilakukan dengan cara merendam serbuk simplisia dalam cairan penyari. Prinsip kerja maserasi yaitu cairan penyari akan menembus dinding sel dan akan masuk ke dalam rongga sel yang mengandung zat aktif. Zat aktif akan larut karena adanya perbedaan konsentrasi antara larutan zat aktif didalam sel dan diluar sel, maka larutan yang paling pekat akan terdesak keluar. Peristiwa tersebut akan berulang sampai terjadi keseimbangan konsentrasi antara larutan di luar dan di dalam sel. Alasan penggunaan metode ekstraksi ini karena bahan atau zat aktif yang terkandung di dalam simplisia tersebut belum diketahui stabilitasnya terhadap pemanasan, dan peralatan yang digunakan sederhana. Cairan penyari yang digunakan dalam proses maserasi ini adalah etanol 96\%. Etanol yang digunakan sebagai cairan penyari karena tidak beracun, netral, absorbsinya baik. Berdasarkan hasil uji penapisan fitokimia, fraksi daun salam positif mengandung senyawa metabolit sekunder, yaitu flavonoid, alkaloid, 
saponin, tanin, fenolik dan triterpenoid. Hal ini sesuai dengan literatur yang diperoleh bahwa daun salam memiliki kandungan senyawa metabolit sekunder yaitu flavonoid, alkaloid, saponin, tanin, fenolik dan triterpenoid (Nur Indah, 2015). Hewan uji yang digunakan dalam penelitian ini berupa tikus putih jantan (Rattus norvegicus). Alasan penggunaan tikus putih jantan karena memiliki sistem hormonal yang stabil dibandingkan dengan tikus betina dan tikus putih jantan juga mempunyai kecepatan metabolisme obat yang lebih cepat dibanding tikus betina (Mcphee, et al., 2007). Untuk memperkecil variabilitas antar hewan uji, maka hewan yang digunakan harus mempunyai keseragaman bobot yaitu berat badan antara 150-200 gram, umur 3-4 bulan. Tikus diadaptasikan selama 2 minggu untuk menyesuaikan pola hidup dan mencegah terjadinya stres pada saat perlakuan.

Pengujian efek dari fraksi daun salam terhadap kadar kolesterol total menggunakan hewan uji tikus putih jantan sebanyak 30 ekor yang dibagi dalam 6 kelompok perlakuan masing-masing kelompok terdapat 5 ekor tikus. 6 kelompok tersebut yaitu kelompok kontrol normal yang hanya diberi pakan standar, kelompok kontrol negatif yang diberi Na CMC 0,5\% kelompok Kontrol positif yang diberi suspense simvastatin dan 3 kelompok perlakuan yang diberi pakan tinggi kolesterol selama 4 minggu dan dilanjutkan dengan pemberian streptozotocin melalui i.p (Intraperitoneal), setelah itu 3 kelompok perlakuan diberi fraksi daun salam yaitu fraksi n-heksan, etil asetat dan etanol air dengan dosis masing-masing $200 \mathrm{mg} / \mathrm{kg}$ BB selama 2 minggu. Kelompok kontrol normal digunakan sebagai pembanding dengan kelompok perlakuan dan kelompok kontrol negatif. Kelompok kontrol negatif digunakan untuk memastikan adanya peningkatan kadar kolesterol total akibat pemberian pakan tinggi kolesterol dan streptozotocin.

Penelitian ini dilakukan untuk melihat efek dari fraksi daun salam terhadap kadar kolesterol total, dengan mengukur kadar darah tikus putih jantan sebelum induksi yang diukur pada awal penelitian, setelah diberi pakan tinggi kolesterol dan dilanjutkan induksi streptozotocin, setelah pemberian fraksi daun salam hari ke-38 dan hari ke-45 untuk melihat efek jangka pendek dan jangka panjang. Analisis data dilakukan dengan menggunakan uji statistik one way Anova, 
untuk melihat adanya perbedaan yang signifikan dengan nilai $p<0,05$ atau $(p=0,000)$, jika terdapat perbedaan maka dilanjutkan dengan uji lanjut Pos Hoc LSD untuk melihat perbedaan yang bermakna antara kelompok perlakuan dengan kelompok normal dan negatif.

Hasil statistik one way Anova kadar kolesterol total pada hari ke-0 memperlihatkan nilai $(p>0,05)$, yaitu $\mathrm{p}=0.290$, yang menunjukkan tidak terdapat perbedaan signifikan pada 3 kelompok perlakuan (fraksi daun salam dosis 200 $\mathrm{mg} / \mathrm{kg}$ BB) dengan kontrol normal dan kontrol negatif. Hal ini dikarenakan pada hari ke-0 kadar kolesterol darah semua hewan uji masih dalam rentang normal.

Hasil statistik one way Anova kadar kolesterol total pada hari ke-31 setelah pemberian pakan tinggi kolesterol dan induksi streptozotocin, mengalami peningkatan yang signifikan dibandingkan dengan Kontrol normal dengan memperlihatkan nilai $(p<0,05)$, yaitu $\mathrm{p}=0,000$. sehingga dilanjutkan dengan uji lanjut Pos Hoc LSD untuk melihat perbedaan yang bermakna antar kelompok perlakuan. Hasil uji lanjut Pos Hoc LSD kadar kolesterol total pada hari ke-31 menunjukkan bahwa kelompok Kontrol positif, Kontrol sakit dan
3 kelompok perlakuan (fraksi n-heksan, etil asetat dan etanol air daun salam dosis 200 $\mathrm{mg} / \mathrm{kg} \mathrm{BB})$ berbeda signifikan dengan kelompok normal. Hal ini dikarenakan kontrol normal tidak diinduksi dengan pakan tinggi kolesterol dan streptozotocin.

Hasil statistik one way Anova kadar kolesterol total pada hari ke-38, memperlihatkan nilai $(p<0,05)$, yaitu $\mathrm{p}=0,000$ untuk kadar kolesterol total menunjukkan terdapat perbedaan signifikan pada 3 kelompok perlakuan (fraksi n-heksan, etil asetat, etanol air daun salam dosis $200 \mathrm{mg} / \mathrm{kg}$ BB), kontrol normal, Kontrol positif dan kontrol negatif, sehingga dilanjutkan dengan uji lanjut Pos Hoc LSD untuk melihat perbedaan yang bermakna antar kelompok perlakuan.

Hasil uji lanjut Pos Hoc LSD kadar kolesterol total pada hari ke-38 menunjukkan bahwa Kontrol negative berbeda signifikan dengan Kontrol normal, Kontrol positif, dan fraksi n-heksan. Tetapi berbeda tidak signifikan dengan kelompok fraksi etil asetat dan fraksi etanol air. ini dikarenakan senyawan aktif dalam daun salam yaitu flavonoid yang bersifat sebagai hipolipidemia dan antioksidan yang dapat menghambat stress oksidatif. Dengan penghambatan stress reaksi oksidasi 
kolesterol LDL maka dapat menurunkan kadar kolesterol darah (Irmadoly, 2014)

Hasil uji statistic one way Anova kadar kolesterol total pada hari ke-45 setelah pemberian fraksi daun salam memperlihatkan nilai $(\mathrm{p}<0,05)$, yaitu $\mathrm{p}=0,000$ untuk kadar kolesterol total menunjukkan terdapat perbedaan signifikan dari semua kelompok perlakuan. Artinya daun salam memiliki pengaruh dalam menurunkan kadar kolesterol total darah tikus putih jantan yang diinduksi pakan tinggi kolesterol dan streptozotocin. Sehingga dilanjutkan dengan uji lanjut Post Hoc LSD untuk melihat perbedaan yang bermakna antar kelompok perlakuan.

Hasil uji lanjut Pos Hoc LSD kadar kolesterol total pada hari ke-45 menunjukkan bahwa fraksi n-heksan daun salam berbeda tidak signifikan dengan Kontrol positif, Kontrol normal, dan fraksi etanol air daun salam. Tetapi berbeda signifikan dengan fraksi etil asetat daun salam dan Kontrol negatif. Dari penelitian didapatkan bahwa tikus yang diinduksi pakan tinggi kolesterol dan streptozotocin dapat menaikkan kadar kolesterol total darah. Hal ini sesuai dengan literatur yang menyatakan bahwa pemberian pakan kolesterol tinggi yang terdiri dari kuning telur dan pig oil dapat meningkatkan kadar kolesterol tikus. Telur bebek merupakan sumber kolesterol yang tinggi karena setiap 100 gram kuning telur bebek mengandung 1000 mg kolesterol (Sutama. 2008).

Hasil penelitian sebelumnya menyatakan bahwa kuning telur bebek sebanyak 2 gram/200 gram BB tikus putih dapat menaikan kadar kolesterol (Ariantari, dkk. 2010). Setiap 100 gram pig oil mengandung asam palmitat (16:0) 26 gram, asam stearat (18:0) 14 gram, asam oleat 918:1) 44 gram, asam linoleat (18:3) 10 gram. Pig oil mempunyai kandungan kolesterol yang lebih tinggi dibandingkan dengan minyak hewani lainnya dan minyak nabati. Pig oil pada usus tikus putih akan disintesis menjadi trigliserida dan didistribusikan dalam bentuk kilomikron. Pemberian streptozotocin menyebabkan terjadinya resistensi insulin sehingga menaikkan kadar glukosa darah, akibatnya hewan uji mengalami diabetes dan terjadi gangguan metabolisme pada lipid dan hormon sensitif lipase diaktifkan. Hal ini menyebabkan kadar lemak dalam sirkulasi darah meningkat dan dalam jaringan adiposa menurun, selain itu aktifnya hormon sensitif lipase menyebabkan asam lemak bebas dalam plasma meningkat. Pemberian pakan 
tinggi kolesterol dihentikan pada hari ke-28 dan diganti dengan pemberian pakan standar dan air minum. Pemberian fraksi daun salam dengan dosis masing-masing

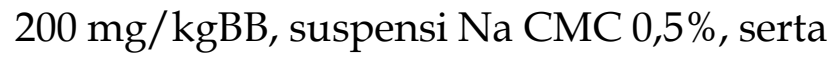
suspensi Simvastatin $0,9 \mathrm{mg} / \mathrm{kg}$ BB sesuai kelompok perlakuan selama 14 hari dengan dua kali pengukuran kadar kolesterol yaitu hari ke-38 dan hari ke-45.

Pada perlakuan tikus yang diberikan obat simvastatin dan fraksi daun salam dosis $200 \mathrm{mg} / \mathrm{kg}$ BB memiliki pengaruh terhadap kadar kolesterol total darah. Hal ini disebabkan karena adanya kendungan senyawa flavonoid, tannin, polifenol, saponin, triterpenoid dan alkaloid. Senyawa flavonoid, tannin dan polifenol yang terkandung di dalam fraksi daun salam yang bersifat sebagai antioksidan telah mampu mereduksi LDL (Low Density Lipoprotein) dan trigliserida, sehingga menghambat penumpukan LDL di dinding pembuluh darah serta senyawa flavonoid dan tannin pada dosis yang digunakan sudah dapat menghambat kerja enzim 3hidroksi 3-metilglutarin koenzim A reduktase (HMG Ko-A reduktase).

Hasil penelitian menunjukkan bahwa daun salam selain memiliki pengaruh dalam menurunkan kadar kolesterol total darah, ternyata juga memiliki efektivitas sebagai antidiabetes, asam urat, hipertensi, diare dan sakit maag (gastritis). Selain sebagai obat, daun salam juga dikenal sebagai bumbu masakan karena aromanya yang khas (Utami, 2008).

Penelitian yang dilakukan menunjukkan fraksi daun salam yaitu nheksan, etil asetat dan etanol air dengan dosis masing-masing $200 \mathrm{mg} / \mathrm{kgBB}$ memiliki pengaruh dalam menurunkan kadar kolesterol total darah tikus putih jantan yang diinduksi pakan tinggi kolesterol dan streptozotocin, dimana fraksi n-heksan daun salam merupakan fraksi yang paling efektif sebagai antikolesterol diabetes dibandingkan fraksi etil asetat dan fraksi etanol air karena efek yang diberikan sebanding dengan kontrol positif simvastatin.

\section{KESIMPULAN}

Berdasarkan hasil penelitian maka dapat:

1. Fraksi daun salam (Syzygium polyanthum (Wight) Walp) menurunkan kadar kolesterol tikus putih jantan (Rattus norvegicus) hiperkolesterolemia.

2. Fraksi N-heksan daun salam dosis $200 \mathrm{mg} / \mathrm{kg}$ BB merupakan fraksi yang efektif menurunkan kadar kolesterol. 
SARAN

Berdasarkan hasil penelitian maka disarankan untuk penelitian selanjutnya sebagai berikut:

1. Perlu penelitian lebih lanjut untuk melihat ada tidaknya potensi toksisitas pada fraksi daun salam.

2. Perlu dilakukan uji klinik langsung terhadap penderita hiperkolestero lemiadiabetes pada manusia.

\section{DAFTAR PUSTAKA}

Irmadoly nini, dkk. 2014. Uji Aktivitas Antidislipidemia In Vivo Fraksi Ekstrak Daun Salam (Eugenia polyantha) pada Tikus Galur Wistar yang diinduksi Diet Tinggi Lemak. Jurnal kedokteran dan kesehatan, Vol.1 No.1.

Devi Hidayat M. dkk. 2017. Kegiatan Antioksidan Syzygium polyanthum Ekstrak. Journal Indonesia, Vol.1, hal. 49-53.

Mcphee, Stephen J. et al. (2007). Current Medical Diagnosis \& Treatment. Lange Mc Graw Hill.

Megawati Widharma R, dkk.2015. Antidiabetes Pengaruh Berair Ekstrak Campuran Andrographis paniculata dan Syzygium polyanthum. Tanaman Obat Journal eropa Nur Indah S. 2015. The Effect of Eugenia polyan tha Extract on LDL Cholesterol. Artikel review. Vol. 4 No. 5 Hal. 85,86

Prahastuti S. et al. 2011. Efek Infusa Daun Salam (Syzygium polyanthum Wight Walp)
Terhadap Penurunan Kadar Kolesterol Total Darah Tikus Model Dislipidemia Galur Wistar. Jurnal Medika Planta. Vol.1 No.4 Hal 31.

Ratnawati H. et al. 2015. Efek Ekstrak Etanol Daun Salam (Syzygium polyanthum Wight Walp) Terhadap Kadar Kolesterol Total Serum Tikus Wistar Jantan Yang Diinduksi Pakan Tinggi Lemak Dibandingkan Simvastatin. Journal Farmakologi. Hal. 5. 